\title{
Piper methysticum G. Forst (Piperaceae) in the central nervous system: phytochemistry, pharmacology and mechanism of action
}

\author{
Piper methysticum G. Forst (Piperaceae) no sistema nervoso central: fitoquímica, farmacologia e \\ mecanismo de ação \\ Piper methysticum G. Forst (Piperaceae) en el sistema nervioso central: fitoquímica, farmacología y \\ mecanismo de acción
}

Patrícia e Silva Alves

ORCID: https://orcid.org/0000-0003-0839-9936 Federal University of Piauí, Brazil E-mail: patriciaesilvalves@gmail.com Felipe Pereira da Silva Santos ORCID: https://orcid.org/0000-0001-9079-952X Federal University of Piaú, Brazil E-mail: felipe.p.santos1@hotmail.com

Ana Paula Rodrigues

ORCID: https://orcid.org/0000-0002-4631-692X Federal University of Piauí, Brazil E-mail: anapaulasousa.01.12@gmail.com

Leandro Sousa Dias

ORCID: https://orcid.org/0000-0002-9087-0194 Federal Institute of Maranhão, Brazil

E-mail: leandrodesousadias98@gmail.com

Giovanna Carvalho da Silva

ORCID: https://orcid.org/0000-0002-9163-1822

Federal Institute of Maranhão, Brazil E-mail: s.giovana@acad.ifma.edu.br

Lidiane da Silva Araújo

ORCID: https://orcid.org/0000-0003-3111-7925

Federal Institute of Maranhão, Brazil E-mail: lidianepiaui@yahoo.com.br

Antonio do Nascimento Cavalcante ORCID: https://orcid.org/0000-0002-8179-0598 Federal Institute of Maranhão, Brazil E-mail: ant_cavalcante@yahoo.com.br

Mahendra Rai

ORCID: https://orcid.org/0000-0001-7645-9801

University Sant. Gadge Baba Amravati, India E-mail: indobraz77@gmail.com

Teresinha de Jesus Aguiar dos Santos Andrade ORCID: https://orcid.org/0000-0002-2415-9222 Federal Institute of Maranhão, Brazil E-mail: teresinha.andrade@ifma.edu.br Chistiane Mendes Feitosa ORCID: https://orcid.org/0000-0001-8013-1761 Federal University of Piauí, Brazil E-mail: chistiane@ufpi.edu.br

\begin{abstract}
Due to the continuous increase in incidents of diseases and disorders in the central nervous system as neurodegenerative disease, the growth of studies that seek to use herbal medicines has been observed, since these are more easily produced and more economically viable, in addition to having side effects to a lesser extent when compared to existing synthetic drugs. In this way, a wide variety of plants have been analyzed for their medicinal purposes and this review presents papers published from 1970 to 2021 that describe the chemical composition pharmacological activities and elucidates mechanisms of action in the central nervous system (CNS) of the species Piper methysticum (Kava-kava). The Kava-kava has a class of compounds that include tannins, alkaloids, benzoic acid, cinnamic acid, sugars, bornyl-cinnamate, stigmasterol, flavocavaines, mucilages, pyrones, tetrahydroiangonins,
\end{abstract}


phytochemicals that are responsible for the pharmacological activities of this plant being thus more studied as anxiolytic, sedative and neuroprotection. Some action mechanisms that describe the performance of kava in the CNS were also addressed, Being the main ones related to blocking of sodium and calcium ion channels, modulation of the erythroid 2 pathway, to receptors such as $\gamma$-aminobutyric acid, glutamatergics, glycine and cannabinoid, as well as monoamine oxidase and acetylcholinesterase enzymes, in addition to neurotransmitters such as dopamine, serotonin and norepinephrine. Therefore, this study aims to open new paths for more in-depth pharmacological studies on Kavakava, and its use in the central nervous system.

Keywords: Piper methysticum; Kava-kava; Phytochemistry; Pharmacology; Mechanism of action.

\begin{abstract}
Resumo
Devido ao aumento continuo das incidências de doenças e distúrbios no sistema nervoso central como as doenças neurodegenerativas, tem-se observado o crescimento de estudos que buscam utilizar medicamentos fitoterápicos, visto que estes são mais facilmente produzidos e economicamente mais viáveis, além de apresentarem efeitos colaterais em menor proporção quando comparados aos medicamentos sintéticos já existentes. Desta forma uma ampla variedade de plantas vem sendo analisadas quanto aos seus fins medicinais e esta revisão apresenta trabalhos publicados de 1970 a 2021 que descrevem sobre a composição química, atividades farmacológicas e elucida mecanismos de ação no SNC da espécie Piper methysticum (Kava-kava). A Kava-kava possui uma classe de compostos que incluem taninos, alcaloides, ácido benzóico, ácido cinâmico, açúcares, bornil-cinamato, estigmasterol, flavocavaínas, mucilagens, pironas, tetrahidroiangoninas, fitoquímicos estes que são responsáveis pelas atividades farmacológicas deste vegetal, sendo as mais estudadas as ansiolíticas, sedativa e de neuroproteção. Também foi abordado alguns dos mecanismos de ação que descrevem a atuação da kava no SNC, sendo os principais relacionados ao bloqueio de canais de íon de sódio e cálcio, a modulação da via do eritroide 2 , a receptores como o ácido $\gamma$-aminobutírico, glutamatérgicos, glicina e canabinoide, como também as enzimas monoamina oxidase e acetilcolinesterase, além de neurotransmissores como dopamina, serotonina e noradrenalina. Portanto, este estudo tem como perspectiva abrir novos caminhos para estudos farmacológicos mais aprofundados sobre Kava-kava e sua utilização no sistema nervoso central.
\end{abstract}

Palavras-chave: Piper methysticum; Kava-kava; Fitoquímica; Farmacologia; Mecanismo de ação.

\title{
Resumen
}

Debido al continuo aumento de la incidencia de enfermedades y trastornos en el sistema nervioso central como las enfermedades neurodegenerativas, se ha observado el crecimiento de estudios que buscan utilizar hierbas medicinales, ya que son más fáciles de producir y económicamente más viables, además de tener efectos secundarios en menor medida en comparación con las drogas sintéticas existentes. Así, se ha analizado una amplia variedad de plantas con fines medicinales y esta revisión presenta trabajos publicados desde 1970 hasta 2021 que describen la composición química, actividades farmacológicas y dilucidan los mecanismos de acción en el SNC de la especie Piper methysticum (Kava-kava). La kava-kava tiene una clase de compuestos que incluyen taninos, alcaloides, ácido benzoico, ácido cinámico, azúcares, cinamato de bornilo, estigmasterol, flavocavinas, mucílagos, pironas, tetrahidroyangoninas, fitoquímicos que son los responsables de las actividades farmacológicas de este vegetal, siendo el Los ansiolíticos, sedantes y neuroprotectores han sido los más estudiados. También se abordaron algunos de los mecanismos de acción que describen la acción de la kava en el SNC, siendo los principales los relacionados con el bloqueo de los canales iónicos de sodio y calcio, la modulación de la vía eritroide 2 , a receptores como el ácido $\gamma$-aminobutírico, glutamatérgico, glicina y cannabinoide, así como las enzimas monoamino oxidasa y acetilcolinesterasa, además de neurotransmisores como dopamina, serotonina y norepinefrina. Por lo tanto, este estudio tiene la perspectiva de abrir nuevos caminos para más estudios farmacológicos sobre Kava-kava y su uso en el sistema nervioso central.

Palabras clave: Piper methysticum; Kava-kava; Fitoquímica; Farmacología; Mecanismo de acción.

\section{Introduction}

The central nervous system (CNS), which acts as an integral part of the nervous system, is associated with a number of important functions and consists mainly of the brain and spinal cord (Uddin \& Zidorn, 2020). CNS diseases and disorders encompass a wide range of pathologies that include neurodegenerative diseases (eg, Alzheimer's and Parkinson's), psychiatric conditions (which include, anxiety, depression and psychosis), epilepsy, multiple sclerosis, neuropathic pain, autism, among others (Goyal et al., 2014; DiNunzio et al., 2008).

Studies have revealed that in recent years, these disorders are widening due to increased life expectancy and therefore represent a huge burden for families and social economies (Kundap et al., 2017). Research has also indicated that neurological disorders were the leading cause of disability-adjusted life years ( 280 million $)$ and the second leading cause of deaths $(\sim 9.0$ million) globally (Lin et al., 2020). In addition, according to the World Health Organization (WHO) neurological disorders affect 
up to one billion people worldwide, among whom 6.8 million people die each year.

Thus, strategies and relative mechanisms capable of defending the CNS against neuronal injuries resulting from acute neurodegenerative diseases (stroke and traumatic brain injury) and chronic (Alzheimer's disease and Parkinson's disease) are needed (Iriti et al., 2010). In addition, with the aging of the population, these pathologies and other brain disorders (Epilepsy and Dementia) are increasing worldwide and culminating in a relevant health problem (Kantati et al., 2016).

To defend the CNS against a series of factors, such as structural defects, infections, neuronal damage, autoimmune diseases, tumors and neurodegeneration, there are drugs that act on the nervous system, represent a large part of those used by the Brazilian population and are involved in occurrence of several adverse reactions (Carlini \& Nappo, 2003; Camargo et al., 2006).

As reported by Carlini and Nappo1 (2003), of the 552.6 million prescriptions made, 74.9 million (13.6\%) of the drugs prescribed corresponded to psychoactive medications. These authors demonstrated in the article The pharmacovigilance of psychoactive medications in Brazil that antidepressant, neuroleptic and antiepileptic drugs were involved in the main records of suspected adverse reactions, causing, for the most part, hospitalization or prolonged hospitalization, risk of life, temporary disability of patients. patients and even deaths (Fonteles et al., 2009).

In this sense, considering the expressive use of these drugs, and with the view that they can have adverse reactions, medicinal plants appear, they have played an important role in the treatment of various neuronal and pathological disorders and are considered safe, effective in sensitive diseases and complicated as CNS disorders, having fewer side effects than synthetic compounds (Kumar et al., 2012). A recent report estimates that approximately $84 \%$ of drugs approved for the treatment of CNS diseases are natural products or inspired by natural products (Lin et al., 2020).

Among medicinal plants, stands out (Piper methysticum G. Forst), popularly known as kava-kava, intoxicating pepper, yagona, among other names. It belongs to the family Piperaceae and genus piper, it is used as a psychoactive drink, prepared from the rhizome of the plant drug, due to its narcotic and sedative properties, which conferred well-being and reduced fatigue (Chanwai, 2000).

The active group of this species acts on the central nervous system (Carlini, 2003), mild depression (Cagnacci et al., 2003) and insomnia (Volz \& Kieser, 1997). Kava has also been shown to be effective in minimizing anxiety-related symptoms and being used in the treatment of stress-related disorders, among other psychiatric illnesses (Petersen et al., 2019). Kavalactones are the main constituents of the plant, presenting significant action as a muscle-skeletal relaxant. However, the mechanisms of action of kavalactones in the central nervous system are still unclear (Palioto \& Rocha, 2013).

Thus, this review aims to provide a critical analysis of the phytochemical and pharmaceutical potential of Piper methysticum, show the natural compounds obtained from it and elucidate its mechanism of action, whose studies could be promising for the development of new herbal medicines against pathologies that act in the central nervous system.

\section{Methodology}

In this study, an integrative review was performed using Web-based databases, including PubMed, Scopus, ScienceDirect and Web of Science, which refer to phytochemistry, pharmacology and mechanism of action of the kava-kava specie (Piper methysticum). The research descriptors used were "Kava-kava in the central nervous system", "phytochemicals and isolates of P. methysticum", "kava-kava for the treatment of diseases", as well as their English language correspondents. 


\section{Results and Discussion}

\subsection{Phytochemistry}

Kava extract is a herbal medicine widely used worldwide for anxiety treatments. In 2001, it was among the most sold herbs in the United States (Blumenthal, 2002). According to Cordeiro et al. (2005) kava-kava presents in its chemical composition several substances, such as tannins, benzoic acid, cinnamic acid, sugars, bornyl-cinnamate, stigmasterol, flavocavaines, mucilages, pyrones, tetrahydroiangonins and some minerals, mainly potassium.

Extracts of kava using organic solvents or extraction of supercritical fluid were produced to concentrate the active components in kava that have been associated with beneficial effects. These active components include a unique class of lactones known as kavalactones or kavapironas. It is noteworthy that the constituents of kavalactones can vary their concentration from 3 to $20 \%$ from plant to plant, depending on some procedures such as, harvesting, drying, storage and processing (Justo \& Silva, 2008).

The constituents responsible for the pharmacological activity of the herbal medicine are a mixture of lipophilic lactones structurally related to an $\alpha$-pyrone skeleton, known with anthelmintic activity (Herath et al., 2019), typically 4- methoxy-2pyrones with aromatic styryl or phenylethyl substituents at position 6 (Shulgin, 1973; Jussofie et al., 1994; Seitz et al., 1997). Essential oil and traces of piperidine alkaloids are also present in the plant (Cheng et al., 1988).

Of the kavalactones studied, 18 were identified in the rhizome and root of the species, and of these, the six that have the greatest pharmacological interest are shown in (Figure 1), include: methysticin, dihydromethysticin, kavain, dihydrokavain, yangonin e desmethoxyyangonin, constituting $96 \%$ of the total kavalactone content. In addition, a group of chalcones known as; Flavokavain A, Flavokavain B and Flavokavain C, are commonly found in kava, however, in significantly smaller quantities (Côté et al., 2004; Lebot et al., 2014). Table 1 below describes the constituents of kava.

Figure 1. Chemical structure of the main kavapironas with pharmacological action present in P. methysticum.

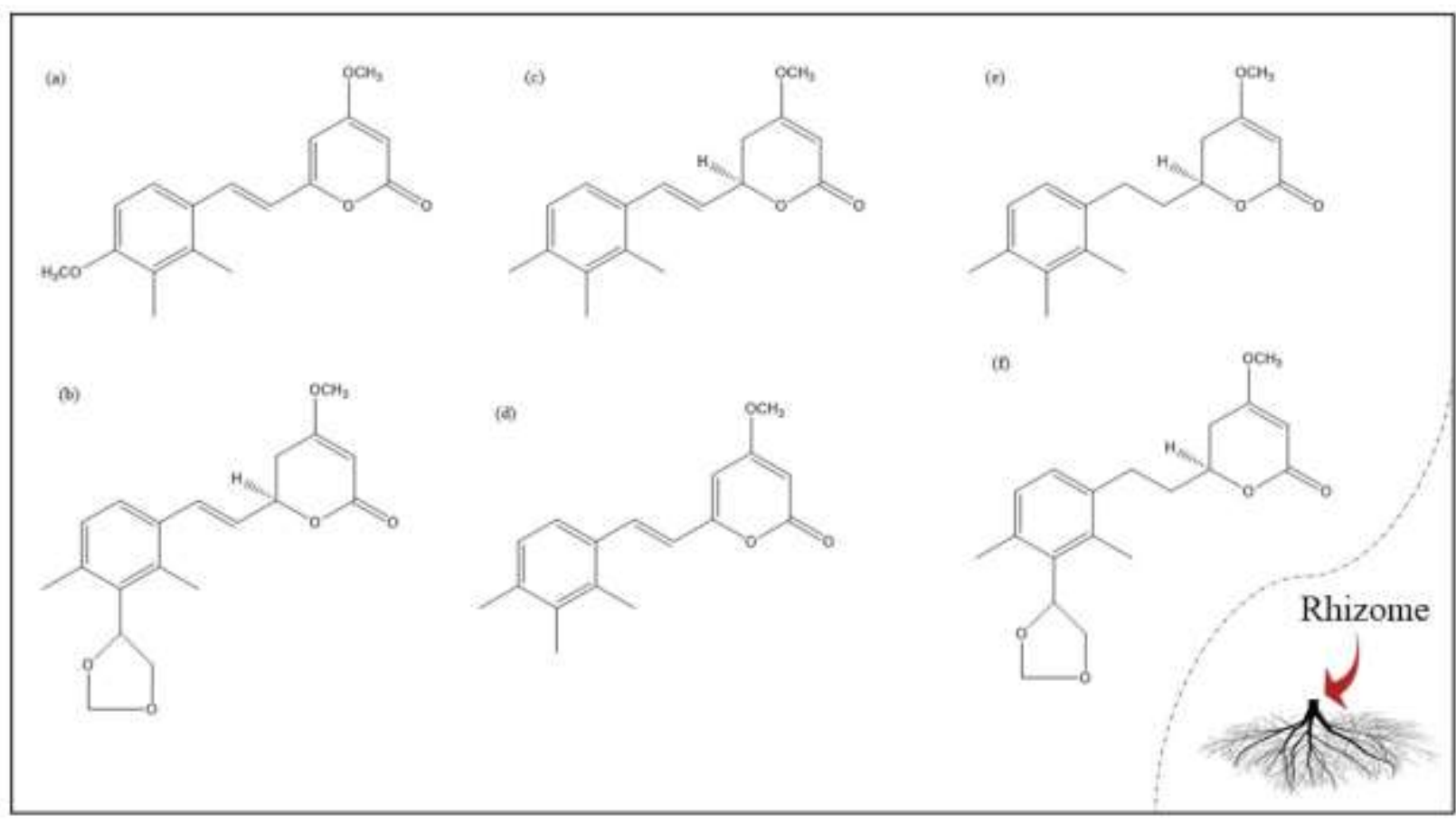

(a) yangonin, ${ }^{(b)}$ methysticin, ${ }^{(\mathrm{c})}$ kavain, ${ }^{(\mathrm{d})}$ desmethoxyyangonin, ${ }^{(\mathrm{e})}$ dihydrokavain, ${ }^{(\mathrm{f})}$ dihydromethysticin. Source: Authors.

However, kavalactones are also present in other parts of the plant and their variability is also strongly affected by the 
geographical location of the crop. The kavalactone content decreases progressively from the roots to the leaves (Duve \& Prasad, 1981) and there is a significant variation in the chemical composition according to the analyzed organ (Smith, 1983; Lebot et al., 1999). Dihydromethysticin and dihydrokavain, are the main components of the leaves and $\mathrm{K}$ and $\mathrm{M}$ are the main components of the roots and rhizome (Smith et al., 1984). According to toxicological data on kavalactones, it is not possible to attribute a potential health hazard to this fraction (Olsen, Frillo, \& Skonberg, 2011).

Table 1. Group of chalcones isolated from the species Piper methysticum.

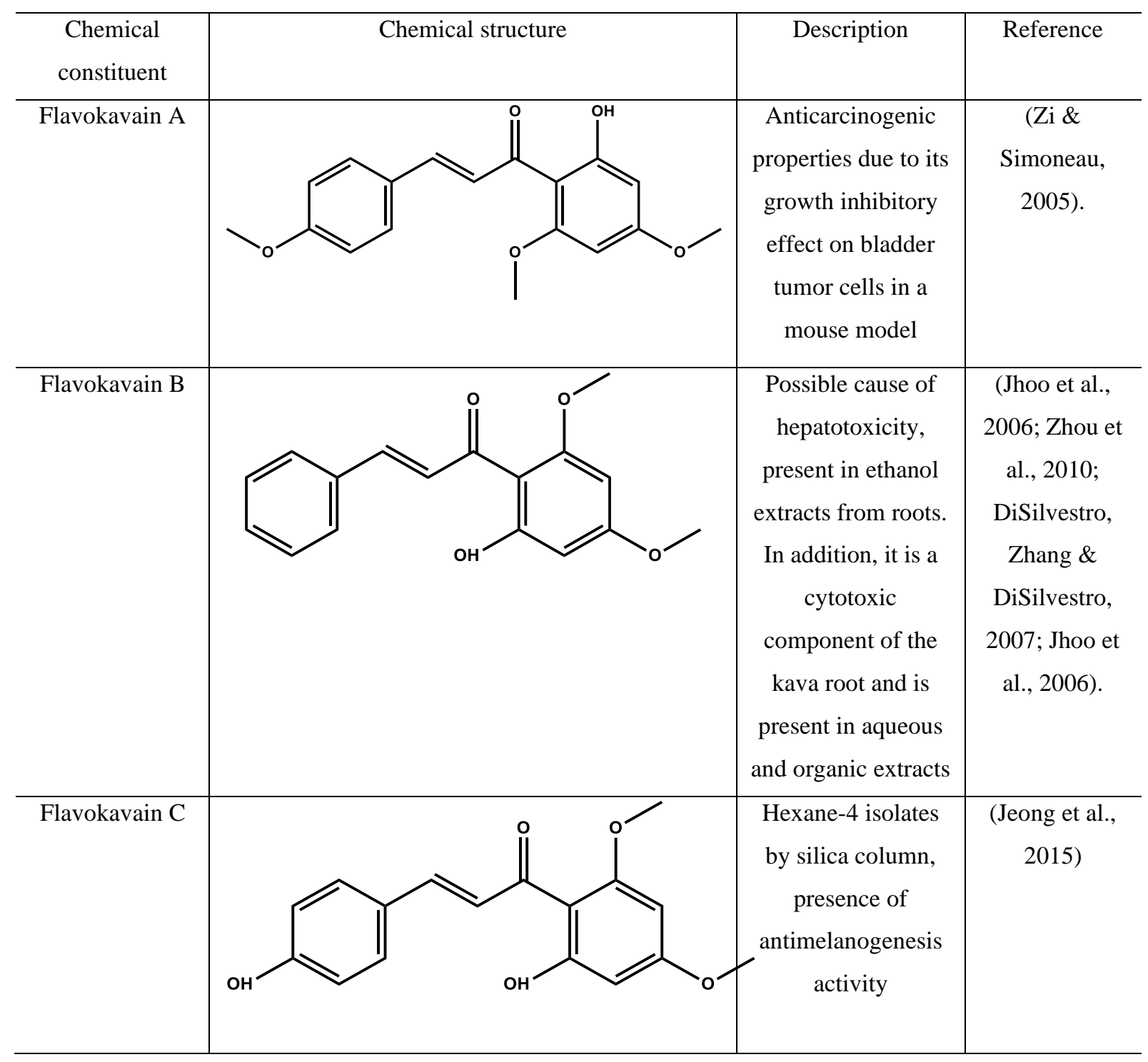

Source: Authors.

New dimeric kavalactones, such as diyangonins (A - C), have also been reported to be isolated from kava roots (Yang, 2019; Yuan et al., 2018). Through GC-EM, it was possible to verify the presence of 7 kavalactones, 3 dihydrocalcones and 19 non-kava lactone compounds. These profiles revealed that $\delta$-cadinol and $\alpha$-epi-7-epi-5 eudesmol are distinctly present in all parts of the tissue of the lateral roots and the crown. Pipermethistine and benzenepropanal were found throughout the stem and hydrokinamic acid was found only in the stem bark. In general, it was found that the crown roots and lateral roots have a greater number of constituents compared to the stems. The common metabolites identified in Gas Chromatography Coupled to Mass Spectrometry (GC-MS) and Liquid Chromatography Coupled to Mass Spectrometry (LC-MS) were 6 kavalactones, previously 
reported, which include (kavain, dihydromethysticin, dihydro5,6 desidrokavain, dihydrokavain, desmetoxianangonin and yangonin), in addition to 3 dihydrocalcones (flavokavain AC) and 2 non-kavalactones (bornyl cinnabar and pipermetistine) (Jaiswal et al., 2020).

Other compounds were isolated from kava, with the active components present in the fat-soluble resin containing three chemical classes (i) arylethylene- $\alpha$-pyrones, (ii) chalcones and other flavones, and (iii) conjugated dienoketones. It is the 4 methoxy-5, 6-dihydro-apirones or substituted kavapironas, commonly known as kavalactones, which have the greatest anxiolytic effects (Fu et al., 2008).

These anxiolytic effects, which are similar to antidepressants, according to studies, may be due to the presence of phytochemicals present in plants, such as saponins, alkaloids, polyphenols, triterpenoids, essential oils, fatty acids and flavonoids have anxiolytic and similar effects to antidepressants (Fajemiroye et al., 2016).

Which, for example, is consistent with the study by Dragull et al. (2003), who describes pipermetisticin, a toxic alkaloid present in the leaves and bark of the kava stem that can contaminate kava products during high production and/or insufficient quality control. This alkaloid is present in aerial parts such as stems, barks of stumps exposed to light and leaves.

Regarding the toxicity of kava, there is a relationship between the preparation method and its toxicity. This is due to reports that identify adverse effects in patients using ethanol/acetone extracts of kava or traditional aqueous extracts, suggesting that toxicity is more dependent on the kava plant itself than on the extraction solvent (s) used (s) (Teschke et al., 2009).

\subsection{Pharmacology in the CNS}

Kava (Piper methysticum) is a well-sold herb in some parts of the world, and its extract is a photochemical used in the treatment of CNS-related diseases, such as anxiety (Becker et al., 2019; Smith \& Leiras, 2018). The maceration of the rhizomes and roots of the plant with the addition of cold water produces a drink known as "kava drink" which, when ingested in high amounts, causes drowsiness and muscle relaxation. This effect caused by the drink drew the attention of western pharmacologists and cynics making the vegetable a target of studies that direct its use as a potential photochemical for anxiety with advantages over existing drugs, such as benzodiazepines (Bian et al., 2020; Thomsen \& Schmidt, 2021).

In addition to the traditional water-based drink, medicines and dietary supplements are also produced from the underground parts of the plant, and their consumption has led to a growing concern related to hepatotoxicity in humans (Teschke et al., 2011; Barbosa et al., 2013). Behl et al. (2011) developed a study in rats and mice in order to assess toxicity and carcinogenicity, and the results obtained suggest that, in fact, the consumption of the supplement causes liver toxicity. Other studies in the literature present cases of acute hepatitis after the use of therapeutic doses of the extract (Justo \& Silva, 2008) and seek to understand the mechanisms involved in order to minimize these unwanted effects (Yang \& Salminen, 2011; Tugcu et al., 2020).

The main factor involved in the hepatotoxicity of this species is believed to be the constituent flavocain $\mathrm{B}$, which has a cytotoxic effect on HepG2 human hepatoma cells, being found mainly in the ethanolic extracts of the plant (Teschke et al., 2011). Although it causes unwanted effects, Kava has a chemical composition rich in kavalactones that induce CNS-related pharmacological activities (Pantano et al., 2016), and clinical studies clarify that its use for this purpose is relatively safe, as it does not cause dependence chemical and is an effective anxiolytic. While synthetic anxiolytics cause lethargy and mental confusion, kava-kava is responsible for the increase in concentration, memory and reflexes of people who have anxiety (Coló, 2006).

Thus, Table 2 presents a review of the pharmacological activities of $P$. methyscum related to the central nervous system, where the psychoactive characteristic of the vegetable is directly related mainly to the anxiolytic, sedative and neuroprotective 
effects.

The use of herbal medicines is quite old. Wong and Atownley (2011) in a discussion about herbal medicines highlights the local anesthetic effect of this species, which when tested in laboratory animals, enhances the sleep time induced by barbiturates, reducing the need for anesthetic agents. This effect is also directly related to anxiolytic activity, which is mainly mediated by the GABA modulation mechanism, and in some tests such as the labyrinth in the cross (performed on mice), the effect is similar to that of the benzodiazepine, Diazepam (Volgin et al., 2020; Rex et al., 2002; Raduege et al., 2004).

It is believed that this test (labyrinth in cross) as well as the cross-chamber avoidance test reflect the state of anxiety in mice, thus in the study conducted by Garrett et al., (2003) using these tests, changes were also observed significant anxiolytictype behavioral disorders. Still following this line Bruner and Anderson (2009) studied the effect of different doses of the extract in order to assess whether this plant shares discriminative stimulus properties with the anxiolytic chlorodiazepoxide (CDP), concluding that the herbal compound can share a similar mechanism to CDP, being just a little less powerful.

Table 2. Pharmacological activities of P. methyscum.

\begin{tabular}{|c|c|}
\hline Pharmacological activity & Reference \\
\hline Local anestesia & $\begin{array}{l}\text { Wong \& Atownley (2011); } \\
\text { Raduege et al. (2004) }\end{array}$ \\
\hline Ansiolítica & $\begin{array}{l}\text { Volgin et al. (2020); Rex et al. (2002); } \\
\text { Sarris et al. (2012); Kuchta et al. (2017); } \\
\text { Sarris et al. (2009); Bruner \& Anderson (2009); } \\
\text { Garrett et al., (2003) }\end{array}$ \\
\hline Anticonvulsant & Jaiswal et al. (2020); Raza et al. (2000) \\
\hline Antipsicótica & Krum et al. (2021) \\
\hline Antidepressants & Sarris et al. (2009) \\
\hline Anti-stress & Wang et al. (2020) \\
\hline Neuroproteção /Neuroinflamação & Fragoulis et al. (2017); Terazawa et al. (2013) \\
\hline Sedative & $\begin{array}{l}\text { Wang et al. (2020); Volgin et al. (2020); } \\
\text { Garrett et al. (2003) }\end{array}$ \\
\hline
\end{tabular}

Source: Authors.

In humans, the work of Kuchta et al. (2017) reported the effectiveness of this effect when evaluating the ethanol extract where a clinical test was developed with patients suffering from anxiety disorder, proving that the extract preparations have this dose-dependent effect, this factor was also observed by other reports of clinical studies, which state that in acute doses of "medicinal level", anxiolytic activity may not be obtained (Sarris et al., 2012). Sarris et al. (2009) in his research, developed the first documented human clinical trial, recruiting adult participants with high generalized anxiety, where from the prescription of 
five pills containing $250 \mathrm{mg}$ of Kava per day, he can prove the effect of the anxiolytic and antidepressant activity of significantly, without problems related to the dose used.

Another important activity was verified by Krum et al. (2021) who investigated the use of Kava extract as an adjuvant that can be applied in the treatment of schizophrenia using a model of symptoms analogous to amphetamine-induced psychosis (AMPH) in rodents, and demonstrates that the extract in addition to helping the symptoms of anxiety, can be a therapeutic potential in psychotic symptoms from the prevention of stereotyped behavior induced by AMPH in mice, becoming the first study carried out to investigate this effect.

Anticonvulsant activities have also been reported in the literature and studies show that structural changes made to piperine (an isolated component of $P$. methyscum) gave rise to seven derivatives, where one of them, known as antiepilepserin, was used as an antiepileptic medication with less effects side effects when compared to other drugs (Raza et al., 2000). Thus, in order to assess the anticonvulsant potential of aqueous extracts from the stems of $P$. methyscum, Jaiswal et al. (2020) performed in vivo tests using zebrafish, and obtained evidence that the plant material used has considerable anticonvulsant properties, especially when applied at a dose of $50 \mathrm{mg} \mathrm{L}^{-1}$, suggesting that this is a species that may be a potential intermediate for the production of medicines for these purposes.

In addition to neuroprotection, mesticin also has sedative effects, which are the first to be observed from this type of kavalactones (Volgin et al., 2020). Studies by Garrete et al. (2003) demonstrated this activity based on tests in mice, where the animal's sedation was observed when noticing a significant decrease in locomotor activity in a circular arena. Wang et al. (2020) used the zebrafish for in vivo tests exposing the animals by immersion in the aqueous extract of the kava roots, and in solutions of pure kavalactones in different concentrations. After behavioral and neurochemical analyzes he observed the sedative effect, depending on the dose used, as an anti-stress effect and also the elevation of dopamine, serotonin and norepinephrine levels, which are related to depressive symptoms.

\subsection{Mechanisms of action in CNS}

The psychoactive species Piper methysticum, popularly known as "Kava" has its pharmacological effects mainly linked to a group of constituents known as kavalactones (Amaral et al., 2008). These are fat-soluble compounds that have activity on multiple neurological disorders such as: anxiolytics, antidepressants, anticonvulsants, sedatives, effects of neuroprotection and neuroinflammation (Singh \& Singh, 2002; Felipe et al., 2007; Chauhan et al.,1988; Capasso \& Sorrentino, 2005; Backhau $\beta$ \& Krieglstein, 1992; Lee \& Tzeng 2015). There are several mechanisms of action that describe these neuropharmacological properties of kava (Bian et al., 2020).

The mechanisms of action linked to the kava CNS described in the literature are: increased binding of the ligand to $\gamma$ aminobutyric acid (GABA) A receptors, reversible inhibition of monoamine oxidase (MAO) B, the blocking of sodium and calcium ion channels, the modulators of the erythroid 2 pathway/antioxidant response element (Nrf2/ARE), the activity of the enzyme acetylcholinesterase (AChE), the activation of N-methyl-D-type glutamatergic receptors -aspartate (NMDA), interaction with cannabinoid receptors, activation of dopaminergic neurons, reduction of serotonin, negative modulation of glycine receptors and reduction of neuronal reuptake of norepinephrine (Volgin et al., 2020; LaPorte et al., 2011). Figure 2 shows a schematic of the kava neuropharmacological mechanisms of action. 
Figure 2. Scheme of the mechanisms of action of kava in the central nervous system (abbreviations in the main text).

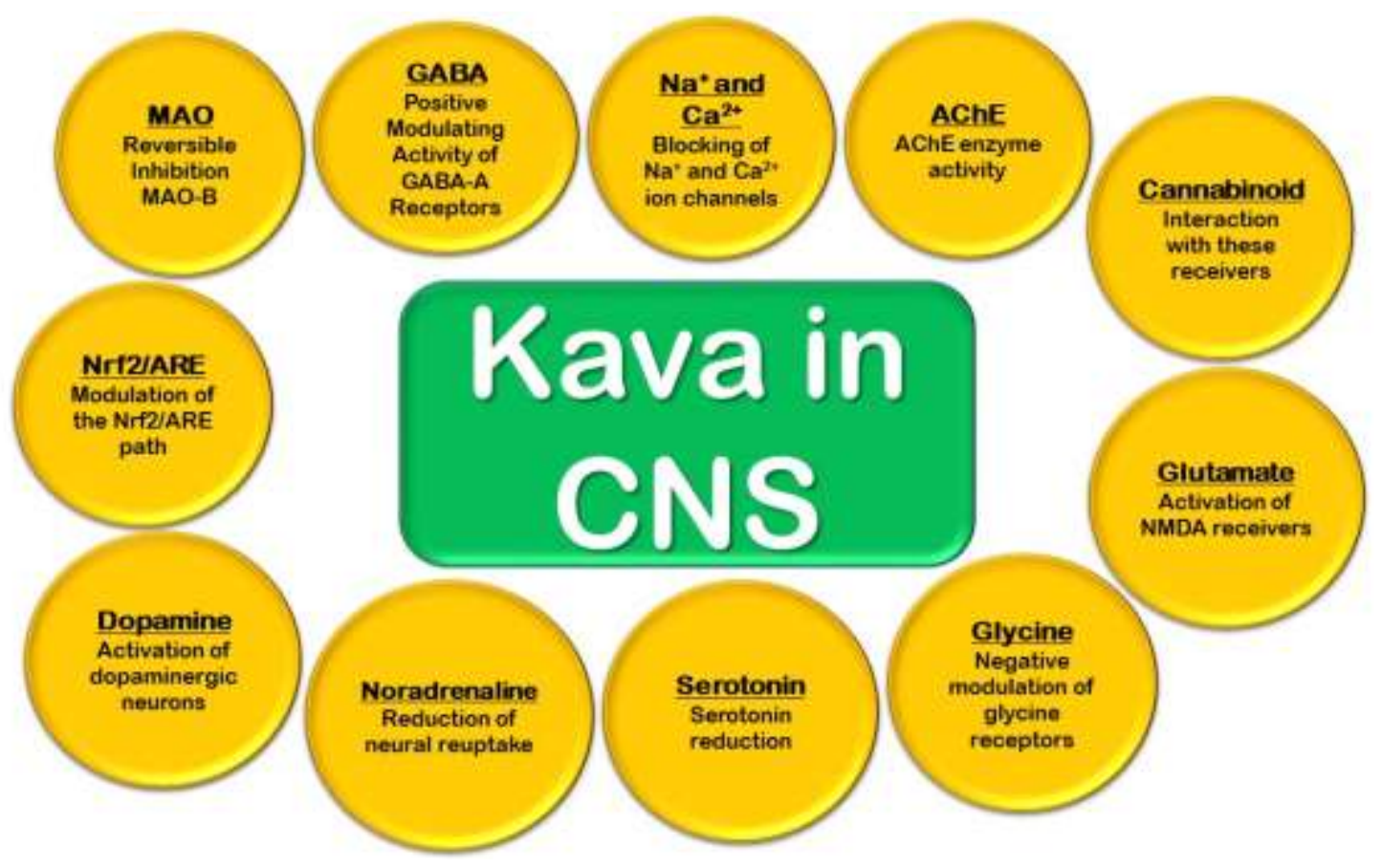

Source: Made by the authors based on Volgin et al. (2020).

For kavalactones Chua et al. (2016) describes in his study the positive modulating activity for GABA-A receptors, with no selectivity. Yuan et al. (2002) reports the increase in the modulation sites in these receptors, in which there is a significant reduction in neuronal discharges. However, a study suggests the absence of effects on GABA-A and GABA-B and benzodiazepine receptors (Davies et al., 1992). A study by Uebelhack et al., (1998) demonstrates the reversible inhibition of MAO-B using both kava extract and isolated kavalactones, this work says that this mechanism may be fundamental for its psychotropic action.

Magura et al. (1997) and Gleitz, Beile and Peters (1996) carried out studies with kavalactones and demonstrated that these compounds are capable of inhibiting specific voltage-gated $\mathrm{Na}^{+}$and $\mathrm{Ca}^{2+}$ channels. Fragoulis et al. (2017) and Wruck et al. (2008) determined in their studies, using bioactive compounds isolated from Piper methysticum, that these substances can activate the Nrf2/ARE pathway, thus being effective in protecting neurons. A work developed by Noor (2010) with Kava showed activity on the enzyme AChE in the hippocampal cholinergic system. Bioactive compounds of kava activated from NMDA type glutamatergic receptors (Walden et al., 1997) and managed to interact with cannabinoid receptors (Ligresti et al., 2012).

The action of extracts and substances isolated from kava related to some neurotransmitters was studied. Baum et al. (1998) carried out a study with the extract and compounds isolated from kava and verified the activation of mesolimbic dopaminergic neurons and the reduction of serotonin. A study carried out with kavalactones suggested the glycinergic activity of kava, in which these substances act as negative modulators of glycine receptors (Hegazy et al., 2019). Heinze et al. (1994) attributed the inhibitory action of kava on the reception of noradrenaline.

\section{Conclusion}

From the review carried out, it can be seen that rhizomes and roots are the parts of kava-kava that are present in the bioactive constituents of this plant in greater quantity, however they are present in lesser quantities in other parts of the plant. The main compounds of this plant are kavalactones, which are mainly related to anxiolytic effects and chalcones that are 
associated with the hepatotoxic effect of this species. The psychoactive characteristic of this vegetable is mainly related to the anxiolytic, sedative and neuroprotective effects. The adverse effects related to the CNS caused by kava are less than those of synthetic drugs already used, however, the use of this vegetable still has a lot to be considered due to the hepatotoxicity caused by the ingestion of the extracts. Although the literature cites several mechanisms of action by which kava performance can occur, there is no precise mechanism that describes the performance of kava in modulating the CNS in clinical models. Thus, more research is needed for the responsible clinical use of kava-kava in the CNS.

\section{References}

Amaral, P. A., Gouault, N., Le Roch, M., Eifler-Lima, V. L., \& David, M. (2008). Towards synthesis of kavalactone derivatives. Tetrahedron Letters, 49 (47), 6607-6609. http://dx.doi.org/10.1016/j.tetlet.2008.07.102

Backhauß, C., \& Krieglstein, J. (1992). Extract of kava (Piper methysticum) and its methysticin constituents protect brain tissue against ischemic damage in rodents. European journal of pharmacology, 215 (2-3), 265-269. http://dx.doi.org/10.1016/0014-2999(92)90037-5

Barbosa, D. R., Lenardon, L., \& Partata, A. K. (2013). Kava-kava (Piper methysticum): uma revisão geral. Revista Científica do ITPAC, 6 (3), 1-19.

Baum, S. S., Hill, R., \& Rommelspacher, H. (1998). Effect of kava extract and individual kavapyrones on neurotransmitter levels in the nucleus accumbens of rats. Progress in Neuro-Psychopharmacology and Biological Psychiatry, 22 (7), 1105-1120. http://dx.doi.org/10.1016/s0278-5846(98)00062-1

Becker, M. W., Lourençone, E. M. S., Mello, A. F., Branco, A., Rodrigues Filho, E. M., Blatt, C. R., Mallmann, C. A., Schneider, M., Caregnato, R. C. A., \& Blatt, C. R. (2019). Liver transplantation and the use of KAVA: Case report. Phytomedicine, 56, 21-26. https://doi.org/10.1016/j.phymed.2018.08.011

Behl, M., Nyska, A., Chhabra, R. S., Travlos, G. S., Fomby, L. M., Sparrow, B. R., Hejtmancik, M. R., \& Chan, P. C. (2011). Liver toxicity and carcinogenicity in F344/N rats and B6C3F1 mice exposed to Kava Kava. Food and chemical toxicology, 49 (11), 2820-2829. https://doi.org/10.1016/j.fct.2011.07.067

Bian, T., Corral, P., Wang, Y., Botello, J., Kingston, R., Daniels, T., Salloum, R. G., Johnston, E., Huo, Z., \& Lu, J. (2020). Kava as a Clinical Nutrient: Promises and Challenges. Nutrients, 12 (10), 3044-3078. http://dx.doi.org/10.3390/nu12103044

Blumenthal, M. (2002). Herb sales down in mainstream market, up in natural food stores. HerbalGram, 55, 60.

Bruner, N., \& Anderson, K. (2009). Discriminative-stimulus and time-course effects of kava-kava (Piper methysticum) in rats. Pharmacology Biochemistry and Behavior, 92, 297-303. https://doi.org/10.1016/j.pbb.2008.12.017

Cagnacci, A., Arangino, S., Renzi, A., Zanni, A. L., Malmusi, S., \& Volpe, A. (2003). Kava-Kava administration reduces anxiety in perimenopausal women. Maturitas, 44 (2), 103-109. https://doi.org/10.1016/S0378-5122(02)00317-1

Chauhan, A. K., Dobhal, M. P., \& Joshi, B. C. (1988). A review of medicinal plants showing anticonvulsant activity. Journal of ethnopharmacology, 22 (1), 1123. http://dx.doi.org/10.1016/0378-8741(88)90226-7

Chua, H. C., Christensen, E. T., Hoestgaard-Jensen, K., Hartiadi, L. Y., Ramzan, I., Jensen, A. A., Absalom, N. L., \& Chebib, M. (2016). Kavain, the major constituent of the anxiolytic kava extract, potentiates GABAA receptors: functional characteristics and molecular mechanism. PLoS One, 11 (6), e0157700. https://doi.org/10.1371/journal.pone.0157700

Camargo, A. L., Ferreira, M. B. C., \& Heineck, I (2006). Adverse drug reactions: a cohort study in internal medicine units at a university hospital. European journal of clinical pharmacology, 62 (2), 143-149. http://dx.doi.org/ 10.1007/s00228-005-0086-7

Capasso, A., \& Sorrentino, L. (2005). Pharmacological studies on the sedative and hypnotic effect of Kava kava and Passiflora extracts combination. Phytomedicine, 12 (1-2), 39-45. http://dx.doi.org/10.1016/j.phymed.2004.03.006

Carlini, E. (2003). Plants and the central nervous system. Pharmacology Biochemistry and Behavior, 75 (3), 501-512. https://doi.org/10.1016/S0091$3057(03) 00112-6$

Carlini, E., \& Nappo, S. A. (2003). The pharmacovigilance of psychoactive medications in Brazil. Brazilian Journal of Psychiatry, 25 (4), $200-205$. https://doi.org/10.1590/S1516-44462003000400004

Chanwai, L. G. (2000). Kava toxicity. Emergency Medicine, 12 (2), 142-145. https://doi.org/10.1046/j.1442-2026.2000.00107.x

Cheng, D., Lidgard, A. O., Duffield, P. H., Duffield, A. M., \& Brophy, J. J. (1988). Identification by methane chemical ionization gas chromatography/mass spectrometry of the products obtained by steam distillation and aqueous acid extraction of commercial Piper methysticum. Biological Mass Spectrometry. 17 (5), 371-376. https://doi.org/10.1002/bms.1200170505

Coló, J. (2006) Trabalho de conclusão de curso (TCC) em farmácia e bioquímica. Kava-kava

Cordeiro, C. H. G., Chung, M., \& Sacramento, L. V. S. (2005). Drug interactions between herbs and medicines: Hypericum perforatum and Piper methysticum. Revista Brasileira de Farmacognosia, 15 (3), 272-278. https://doi.org/10.1590/S0102-695X2005000300019

Côté, C. S., Kor, C., Cohen, J., \& Auclair, K. (2004). Composition and biological activity of traditional and commercial kava extracts. Biochemical and biophysical research communications, 322 (1), 147-152. https://doi.org/10.1016/j.bbrc.2004.07.093 
Davies, L. P., Drew, C. A., Duffield, P., Johnston, G. A., \& Jamieson, D. D. (1992). Kava pyrones and resin: studies on GABAA, GABAB and benzodiazepine binding sites in rodent brain. Pharmacology \& toxicology, 71 (2), 120-126. http://dx.doi.org/10.1111/j.1600-0773.1992.tb00530.x

DiNunzio, J. C., \& Williams III, R. O. (2008). CNS disorders-current treatment options and the prospects for advanced therapies. Drug development and industrial pharmacy, 34 (11), 1141-1167. https://doi.org/10.1080/03639040802020536

DiSilvestro, R. A., Zhang, W., \& DiSilvestro, D. J. (2007). Kava feeding in rats does not cause liver injury nor enhance galactosamine-induced hepatitis. Food and chemical toxicology, 45 (7), 1293-1300. https://doi.org/10.1016/j.fct.2007.01.015

Dragull, K., Yoshida, W. Y., \& Tang, C. S. (2003). Piperidine alkaloids from Piper methysticum. Phytochemistry, 63 (2), 193-198. https://doi.org/10.1016/S0031-9422(03)00111-0

Duve, R. N., \& Prasad, J. (1981). Quality evaluation of Yaqona (Piper methysticum) in Fiji. Fiji agricultural journal, $43,1$.

Fajemiroye, J. O., Silva, D. M., Oliveira, D. R., \& Costa, E. A. (2016). Treatment of anxiety and depression: medicinal plants in retrospect. Fundamental \& clinical pharmacology, 30 (3), 198-215. https://doi.org/10.1111/fcp.12186

Felipe, F. C. B., Sousa Filho, J. T., Oliveira Souza, L. E., Silveira, J. A., Andrade Uchoa, D. E. A., Silveira, E. R., Pessoa, O. D. L., \& Barros Viana, G. S. B. (2007). Piplartine, an amide alkaloid from Piper tuberculatum, presents anxiolytic and antidepressant effects in mice. Phytomedicine, 14 (9), 605-612. http://dx.doi.org/10.1016/j.phymed.2006.12.015

Fonteles, M. M. D. F., Francelino, E. V., Santos, L. K. X. D., Silva, K. M., Siqueira, R., Viana, G. S. D. B., Vasconcelos, S. M. M. D., Sousa, F. C. F. D., \& Monteiro, M. P. (2009). Adverse reaction caused by drugs acting in nervous system: records analysis of a farmacovigilance center in Brazil. Archives of Clinical Psychiatry, 36 (4), 137-144. https://doi.org/10.1590/S0101-60832009000400003

Fragoulis, A., Siegl, S., Fendt, M., Jansen, S., Soppa, U., Brandenburg, L. O., Pufe, T., Weis, J., \& Wruck, C. J. (2017). Oral administration of methysticin improves cognitive deficits in a mouse model of Alzheimer's disease. Redox biology, 12, 843-853. http://dx.doi.org/10.1016/j.redox.2017.04.024

Fu, P. P., Xia, Q., Guo, L., Yu, H., \& Chan, P.C. (2008). Toxicity of kava kava. Journal of Environmental Science and Health Part C, 26 (1), 89-112. https://doi.org/10.1080/10590500801907407

Garrett, K. M., Basmadjian, G., Khan, I. A., Schaneberg, B. T., \& Seale, T. W. (2003). Extracts of kava (Piper methysticum) induce acute anxiolytic-like behavioral changes in mice. Psychopharmacology, 170 (1), 33-41. http://dx.doi.org/10.1007/s00213-003-1520-0

Gleitz, J., Beile, A., \& Peters, T. (1996). ( \pm )-Kavain inhibits the veratridine-and KCl-induced increase in intracellular Ca ${ }^{2+}$ and glutamate-release of rat cerebrocortical synaptosomes. Neuropharmacology, 35 (2), 179-186. http://dx.doi.org/10.1016/0028-3908(95)00163-8

Goyal, K., Koul, V., Singh, Y., \& Anand, A. (2014). Targeted drug delivery to central nervous system (CNS) for the treatment of neurodegenerative disorders: trends and advances. Central Nervous System Agents in Medicinal Chemistry (Formerly Current Medicinal Chemistry-Central Nervous System Agents), 14 (1), 43-59. https://doi.org/10.2174/1871524914666141030145948

Hegazy, N. H., Breitinger, H. G., \& Breitinger, U. (2019). Kavalactones from Kava (Piper methysticum) root extract as modulators of recombinant human glycine receptors. Biological chemistry, 400 (9), 1205-1215. http://dx.doi.org/10.1515/hsz-2019-0112

Herath, H. D., Preston, S., Jabbar, A., Garcia-Bustos, J., Addison, R. S., Hayes, S., Rali, T., Wang, T., Koehler, A. V., Chang, B. C. H., Hofmann, A., Davis, R. A., \& Gasser, R. B. (2019). Selected $\alpha$-pyrones from the plants Cryptocarya novoguineensis (Lauraceae) and Piper methysticum (Piperaceae) with activity against Haemonchus contortus in vitro. International Journal for Parasitology: Drugs and Drug Resistance, 9, 72-79. https://doi.org/10.1016/j.ijpddr.2018.12.006

Heinze, H., Münthe, T., Steitz, J., \& Matzke, M. (1994). Pharmacopsychological effects of oxazepam and kava-extract in a visual search paradigm assessed with event-related potentials. Pharmacopsychiatry, 27 (06), 224-230. http://dx.doi.org/10.1055/s-2007-1014309

Iriti, M., Vitalini, S., Fico, G., \& Faoro, F. (2010). Neuroprotective herbs and foods from different traditional medicines and diets. Molecules, 15 (5), $3517-3555$ https://doi.org/10.3390/molecules 15053517

Jaiswal, Y., Shaikh, M., Wang, I., Yong, Y., Lin Lin Lee, V., \& Williams, L. (2020). Evaluation of Anti-Convulsive Properties of Aqueous Kava Extract on Zebrafish Using the PTZ-Induced Seizure Model. Brain Sciences, 10 (8), 541-552. http://dx.doi.org/10.3390/brainsci10080541

Jaiswal, Y. S., Yerke, A. M., Bagley, M. C., Ekelöf, M., Weber, D., Haddad, D., Fodor, A., Muddiman, D. C., \& Williams, L. L. (2020). 3D Imaging and metabolomic profiling reveal higher neuroactive kavalactone contents in lateral roots and crown root peels of Piper methysticum (kava). GigaScience, 9 (9), giaa096. https://doi.org/10.1093/gigascience/giaa096

Jeong, H. J., Lee, C. S., Choi, J., Hong, Y. D., Shin, S. S., Park, J. S., Lee, J. H., Lee, S., Yoon, K. D., \& Ko, J. (2015). Flavokawains B and C, melanogenesis inhibitors, isolated from the root of Piper methysticum and synthesis of analogs. Bioorganic \& medicinal chemistry letters, 25 (4), 799-802. https://doi.org/10.1016/j.bmcl.2014.12.082Get

Jhoo, J. W., Freeman, J. P., Heinze, T. M., Moody, D., Schnackenberg, L. K., Beger, R. D., Dragull, K., Tang, C. S., \& Ang, C. Y. W. (2006). In vitro cytotoxicity of nonpolar constituents from different parts of kava plant (Piper methysticum). Journal of agricultural and food chemistry, 54 (8), 3157-3162. https://doi.org/10.1021/jf051853j

Jussofie, A., Schmiz, A., \& Hiemke, C. (1994). Kavapyrone enriched extract from Piper methysticum as modulator of the GABA binding site in different regions of rat brain. Psychopharmacology, 116 (4), 469-474. https://doi.org/10.1007/BF02247480

Justo, S. C., Silva, C. M., \& Silva, C. M. (2008). Piper methysticum G. Forster (Kava-Kava): uma abordagem geral. Revista Eletrônica de Farmácia, 5 (1), $73-$ 82. https://doi.org/10.5216/ref.v5i1.4617 
Kantati, Y. T., Kodjo, K. M., Dogbeavou, K. S., Vaudry, D., Leprince, J., \& Gbeassor, M. (2016). Ethnopharmacological survey of plant species used in folk medicine against central nervous system disorders in Togo. Journal of ethnopharmacology, 181, 214-220. https://doi.org/10.1016/j.jep.2016.02.006

Krum, B. N., Freitas, C. M., Ceretta, A. P. C., Barbosa, C. P., Moraes Reis, E., Scussel, R., Córneo, E. S., Machado-de-Ávila, R. A., Boligon, A. A., \& Fachinetto, R. (2021). Kava decreases the stereotyped behavior induced by amphetamine in mice. Journal of ethnopharmacology, 265, 1-9. http://dx.doi.org/10.1016/j.jep.2020.113293

Kuchta, K., Nicola, P., \& Schmidt, M. (2017). Randomized, dose-controlled double-blind trial: Efficacy of an ethanolic kava (Piper methysticum rhizome) extract for the treatment of anxiety in elderly patients. Traditional \& Kampo Medicine, 5 (1), 3-10. http://dx.doi.org/10.1002/tkm2.1079

Kundap, U. P., Bhuvanendran, S., Kumari, Y., Othman, I., \& Shaikh, M. F. (2017). Plant derived phytocompound, embelin in CNS disorders: a systematic review. Frontiers in Pharmacology, 8, 76. https://doi.org/10.3389/fphar.2017.00076

Kumar, H., More, S. V., Han, S. D., Choi, J. Y., \& Choi, D. K. (2012). Promising therapeutics with natural bioactive compounds for improving learning and memory - a review of randomized trials. Molecules, 17 (9), 10503-10539. https://doi.org/10.3390/molecules170910503

LaPorte, E., Sarris, J., Stough, C., \& Scholey, A. (2011). Neurocognitive effects of kava (Piper methysticum): a systematic review. Human Psychopharmacology: Clinical and Experimental, 26 (2), 102-111. http://dx.doi.org/10.1002/hup.1180

Lebot, V., Do, T., \& Legendre, L. (2014). Detection of flavokavins (A, B, C) in cultivars of kava (Piper methysticum) using high performance thin layer chromatography (HPTLC). Food chemistry, 151, 554-560. https://doi.org/10.1016/j.foodchem.2013.11.120

Lebot, V., McKenna, D. J., Johnston, E., Zheng, Q. Y., \& McKern, D. J. (1999). Morphological, phytochemical, and genetic variation in Hawaiian cultivars of'awa (kava, Piper methysticum, Piperaceae). Economic botany, 53 (4), 407-418. http://dx.doi.org/10.1007/BF02866720

Lee, M. J., \& Tzeng, Y. M. (2015). Neuroprotective properties of kavalactones. Neural regeneration research, 10 (6), 875-877. http://dx.doi.org/ 10.4103/16735374.158335

Ligresti, A., Villano, R., Allarà, M., Ujváry, I., \& Di Marzo, V (2012). Kavalactones and the endocannabinoid system: the plant-derived yangonin is a novel CB1 receptor ligand. Pharmacological Research, 66 (2), 163-169. http://dx.doi.org/10.1016/j.phrs.2012.04.003

Lin, S. X., Curtis, M. A., \& Sperry, J. (2020). Pyridine alkaloids with activity in the central nervous system. Bioorganic \& Medicinal Chemistry, 28 (24), 115820. https://doi.org/10.1016/j.bmc.2020.115820

Magura, E. I., Kopanitsa, M., Gleitz, J., Peters, T., \& Krishtal, O. A. (1997). Kava extract ingredients, (+)-methysticin and ( \pm )-kavain inhibit voltage-operated Na+-channels in rat CA1 hippocampal neurons. Neuroscience, 81 (2), 345-351. http://dx.doi.org/10.1016/s0306-4522(97)00177-2

Noor, N. A. (2010). Anxiolytic action and safety of Kava: Effect on rat brain acetylcholinesterase activity and some serum biochemical parameters. African Journal of Pharmacy and Pharmacology, 4 (11), 823-828. https://doi.org/10.5897/AJPP.9000059

Olsen, L. R., Grillo, M. P., \& Skonberg, C. (2011). Constituents in kava extracts potentially involved in hepatotoxicity: a review. Chemical research in toxicology, 24 (7), 992-1002. https://doi.org/10.1021/tx100412m

Palioto, G., \& Rocha, C. (2013). Mutagenic evaluation of Piper methysticum L. f. in Aspergillus nidulans methG1 system. Revista Brasileira de Plantas Medicinais, 15 (3), 347-351. https://doi.org/10.1590/S1516-05722013000300006

Pantano, F., Tittarelli, R., Mannocchi, G., Zaami, S., Ricci, S., Giorgetti, R., Terranova, D., Busardò, F., \& Marinelli, E. (2016). Hepatotoxicity induced by “the 3Ks": kava, kratom and khat. International journal of molecular sciences, 17 (4), 580. http://dx.doi.org/10.3390/ijms17040580

Petersen, G. E., Tang, Y., \& Fields, C. (2019). Chemical and in vitro toxicity analysis of a supercritical fluid extract of Kava kava (Piper methysticum). Journal of ethnopharmacology, 235, 301-308. https://doi.org/10.1016/j.jep.2019.01.032

Raduege, K. M., Kleshinski, J. F., Ryckman, J. V., \& Tetzlaff, J. E. (2004). Anesthetic considerations of the herbal, kava. Journal of clinical anesthesia, 16 (4), 305-311. http://dx.doi.org/10.1016/j.jclinane.2003.08.009

Raza, M., Choudhary, M. I., \& Atta-Ur-Rahman (2000). Medicinal plants with anticonvulsant activities. Bioactive Natural Products (Part C), 22, 507-553. https://doi.org/10.1016/S1572-5995(00)80034-4

Rex, A., Morgenstern, E., \& Fink, H (2002). Anxiolytic-like effects of Kava-Kava in the elevated plus maze test-a comparison with diazepam. Progress in Neuro-Psychopharmacology and Biological Psychiatry, 26 (5), 855-860. http://dx.doi.org/10.1016/s0278-5846(01)00330-x

Sarris, J., Kavanagh, D. J., Byrne, G., Bone, K., Adams, J., \& Deed, G. (2009). The Kava Anxiety Depression Spectrum Study (KADSS): a randomized, placebocontrolled crossover trial using an aqueous extract of Piper methysticum. Psychopharmacology, 205 (3), 399-407. http://dx.doi.org/10.1007/s00213-009-1549-

Sarris, J., Scholey, A., Schweitzer, I., Bousman, C., LaPorte, E., Ng, C., Murray, G., \& Stough, C. (2012). The acute effects of kava and oxazepam on anxiety, mood, neurocognition; and genetic correlates: a randomized, placebo-controlled, double-blind study. Human Psychopharmacology: Clinical and Experimental, 27 (3), 262-269. http://dx.doi.org/10.1002/hup.2216

Seitz, U., Schüle, A., \& Gleitz, J. (1997). [3H]-monoamine uptake inhibition properties of kava pyrones. Planta medica, 63 (06), 548-549. https://doi.org/10.1055/s-2006-957761

Shulgin, A. (1973). The narcotic pepper: the chemistry and pharmacology of Piper methysticum and related species. Bulletin on Narcotics, 25 (2), 59-74. 
Singh, Y. N., \& Singh, N. N. (2002). Therapeutic potential of kava in the treatment of anxiety disorders. CNS drugs, 16 (11), 731-743. http://dx.doi.org/10.2165/00023210-200216110-00002

Smith, K., \& Leiras, C. (2018). The effectiveness and safety of Kava Kava for treating anxiety symptoms: A systematic review and analysis of randomized clinical trials. Complementary therapies in clinical practice, 33, 107-117. http://dx.doi.org/10.1016/j.ctcp.2018.09.003

Smith, R. M. (1983). Kava lactones in Piper methysticum from Fiji. Phytochemistry, 22 (4), 1055-1056. https://doi.org/10.1016/0031-9422(83)85065-1

Smith, R. M., Thakrar, H., Arowolo, T., \& Shafi, A. (1984). High-performance liquid chromatography of kava lactones from Piper methysticum. Journal of Chromatography A, 283, 303-308. https://doi.org/10.1016/S0021-9673(00)96265-4

Terazawa, R., Akimoto, N., Kato, T., Itoh, T., Fujita, Y., Hamada, N., Deguchi, T., Iinuma, M., Noda, M., \& Nozawa, Y. (2013). A kavalactone derivative inhibits lipopolysaccharide-stimulated iNOS induction and NO production through activation of Nrf2 signaling in BV2 microglial cells. Pharmacological Research, 71, 34-43. http://dx.doi.org/10.1016/j.phrs.2013.02.002

Teschke, R., Genthner, A., \& Wolff, A. (2009). Kava hepatotoxicity: Comparison of aqueous, ethanolic, acetonic kava extracts and kava-herbs mixtures. Journal of ethnopharmacology, 123 (3), 378-384. https://doi.org/10.1016/j.jep.2009.03.038

Teschke, R., Qiu, S. X., \& Lebot, V. (2011). Herbal hepatotoxicity by kava: update on pipermethystine, flavokavain B, and mould hepatotoxins as primarily assumed culprits. Digestive and Liver Disease, 43 (9), 676-681. http://dx.doi.org/10.1016/j.dld.2011.01.018

Teschke, R., Sarris, J., \& Lebot, V. (2011). Kava hepatotoxicity solution: A six-point plan for new kava standardization. Phytomedicine, 18 (2-3), 96-103. http://dx.doi.org/10.1016/j.phymed.2010.10.002

Thomsen, M., \& Schmidt, M. (2021). Health policy versus kava (Piper methysticum): Anxiolytic efficacy may be instrumental in restoring the reputation of a major South Pacific crop. Journal of ethnopharmacology, 268, 113582. http://dx.doi.org/10.1016/j.jep.2020.113582

Tugcu, G., Kırmızıbekmez, H., \& Aydın, A. (2020). The integrated use of in silico methods for the hepatotoxicity potential of Piper methysticum. Food and chemical toxicology, 145, 111663. http://dx.doi.org/10.1016/j.fct.2020.111663

Uddin, M. J., \& Zidorn, C. (2020). Traditional herbal medicines against CNS disorders from Bangladesh. Natural Products and Bioprospecting, 10, 1-33. https://doi.org/10.1007/s13659-020-00269-7

Uebelhack, R., Franke, L., \& Schewe, H. J. (1998). Inhibition of platelet MAO-B by kava pyrone-enriched extract from Piper methysticum Forster (kavakava). Pharmacopsychiatry, 31 (05), 187-192. http://dx.doi.org/10.1055/s-2007-979325

Volgin, A., Yang, L., Amstislavskaya, T., Demin, K., Wang, D., Yan, D., Wang, J., Wang, M., Alpyshov, E., \& Hu, G. (2020). DARK Classics in Chemical Neuroscience: Kava. ACS chemical neuroscience, 11 (23), 3893-3904. http://dx.doi.org/10.1021/acschemneuro.9b00587

Volz, H. P., \& Kieser, M. (1997). Kava-kava extract WS 1490 versus placebo in anxiety disorders-a randomized placebo-controlled 25-week outpatient trial. Pharmacopsychiatry, 30 (01), 1-5. https://doi.org/10.1055/s-2007-979474

Walden, J., Von Wegerer, J., Winter, U., Berger, M., \& Grunze, H. (1997). Effects of kawain and dihydromethysticin on field potential changes in the hippocampus. Progress in neuro-psychopharmacology \& biological psychiatry, 21 (4), 697-706. http://dx.doi.org/10.1016/s0278-5846(97)00042-0

Wang, D., Yang, L., Wang, J., Hu, G., Liu, Z., Yan, D., Serikuly, N., Alpyshov, E. T., Demin, K. A., \& Galstyan, D. S. (2020). Behavioral and physiological effects of acute and chronic kava exposure in adult zebrafish. Neurotoxicology and teratology, 79, 106881. http://dx.doi.org/10.1016/j.ntt.2020.106881

Wong, A., \& Townley, S. A. (2011). Herbal medicines and anaesthesia. Continuing Education in Anaesthesia. Critical Care and Pain, 11 (1), $14-17$. http://dx.doi.org/10.1093/bjaceaccp/mkq046

World Health Organization, Bangladesh (2021). https://www.searo.who.int/bangladesh/mental-health/en

Wruck, C. J., Götz, M. E., Herdegen, T., Varoga, D., Brandenburg, L. O., \& Pufe, T. (2008). Kavalactones protect neural cells against amyloid $\beta$ peptide-induced neurotoxicity via extracellular signal-regulated kinase 1/2-dependent nuclear factor erythroid 2-related factor 2 activation. Molecular Pharmacology, 73 (6), 1785-1795. http://dx.doi.org/10.1124/mol.107.042499

Yang, J. X (2019). A new kavalactone dimer from Piper methysticum. Chemistry of Natural Compounds, 55 (4), 606-609. https://doi.org/10.1007/s10600-01902759-8

Yang, X., \& Salminen, W. F. (2011). Kava extract, an herbal alternative for anxiety relief, potentiates acetaminophen-induced cytotoxicity in rat hepatic cells. Phytomedicine, 18 (7), 592-600. http://dx.doi.org/10.1016/j.phymed.2011.02.006

Yuan, C. S., Dey, L., Wang, A., Mehendale, S., Xie, J. T., Aung, H. H., \& Ang-Lee, M. K. (2002). Kavalactones and Dihydrokavain Modulate GABAergic Activity in a Rat Gastric-Brainstem Preparation. Planta Medica, 68 (12), 1092-1096. http://dx.doi.org/10.1055/s-2002-36338

Yuan, Y., Yang, J. X., Nie, L. H., Li, B. L., Qin, X. B., Wu, J. W., \& Qiu, S. X. (2018). Three new kavalactone dimers from Piper methysticum (kava). Journal of Asian natural products research, 20 (9), 837-843. https://doi.org/10.1080/10286020.2017.1367768

Zhou, P., Gross, S., Liu, J. H., Yu, B. Y., Feng, L. L., Nolta, J., Sharma, V., Worms, D. P., \& Qiu, S. X. (2010). Flavokawain B, the hepatotoxic constituent from kava root, induces GSH-sensitive oxidative stress through modulation of IKK/NF-кB and MAPK signaling pathways. The FASEB Journal, 24 (12), $4722-4732$. https://doi.org/10.1096/fj.10.163311

Zi, X., \& Simoneau, A. R. (2005). Flavokawain A, a novel chalcone from kava extract, induces apoptosis in bladder cancer cells by involvement of Bax proteindependent and mitochondria-dependent apoptotic pathway and suppresses tumor growth in mice. Cancer research, 65 (8), $3479-3486$. https://doi.org/10.1158/0008-5472.CAN-04-3803 